\title{
3. Talk and Chalk
}

\author{
Ken Inglis
}

Ken Inglis was professor of history and then vice-chancellor at the University of Papua New Guinea and professor of history at ANU. This remembrance was written for Hank's memorial service, 24 February 2012.

I first heard the name Hank Nelson in February 1966, just 46 years ago, at The Australian National University. I'd been appointed to the chair of history at the so far non-existent University of Papua New Guinea (UPNG), but I wasn't moving until the beginning of 1967. I was asked to find someone to teach history to a group of between 50 and 60 students who were taking a year of preliminary studies that would prepare them for work towards a degree. Bill Gammage, a recent ANU graduate, readily agreed to go. But when he got to Moresby, he found that somebody else was coming to join him. This somebody's name was Hank Nelson. Some American blow-in? It turned out that he was a Melbourne graduate in education then lecturing at RMIT, and that Hank was the name conferred on him at high school.

In mosquito-ridden tin sheds until lately occupied by a firm named Tutt Bryant, Hank and Bill teamed up to teach history to the young men and women - mostly men - aspiring to be their country's first graduates. The Tutt Bryant School of Pacific Studies, Hank and Bill called the incipient university. Hank and Jan, who had met while teaching in Victoria, were married before they went north and had children by the time they arrived. I went up from time to time during 1966 for meetings of the professorial board in one of the sheds and met some of the students at the Nelsons' house.

Hank and Bill, boys from the bush, plain speakers, good listeners, encouragers, seemed to me wonderfully well suited to be mentors for these young people. I recall conversations at the Nelsons' place with future leaders of the country, among them Tony Siaguru, Bernard Sakora, Bart Philemon and Rabbie Namaliu. (Bill reminds me that Charles Lepani was in the second-year intake of preliminary year students, in 1967.) And I remember Hank's well-informed and shrewd briefing on PNG society and culture from the driving seat of a Volkswagen on a hairy journey up into the hills behind Moresby.

Bill came back to Canberra at the end of 1966. Hank, based for a while at the Administrative College and then in the sturdy concrete buildings of UPNG, taught in two courses on PNG history, one introductory, and then one advanced. He also contributed to the Sydney-based fortnightly journal Nation 
on the rapidly changing politics of a nation poised for self-government. Penguin Books, spotting a likely author, commissioned what would become his first book, Papua New Guinea: Black Unity or Black Chaos (1972).

His lectures were always well prepared, clear, and unerringly pitched, neither condescending to students nor overwhelming them. He responded to a hightech lecture theatre, installed in 1969, with some amusement. 'You feel bloody inadequate with just talk and chalk', he said, tongue-in-cheek. In the advanced class he made much use of oral history, simply getting on with it while academics in Australia and elsewhere fussed about the rewards and hazards of the approach. Our external consultant, D.W.A. Baker of ANU, judged this course the best of its kind he had come across.

Hank was a stickler for accuracy, in his own work and in the work of students and colleagues. After a lecture in which I had carelessly sketched the history of federal politics, he said with a smile, 'Hey, you just abolished the Scullin government'.

Beyond the classroom he was a quietly sociable presence at sporting events and barbecues. He was a diligent boundary umpire at Aussie rules matches. $\mathrm{He}$ didn't drink beer, though he was no wowser.

When I think of the special regard for Hank among students, this story comes to mind: It's 7:30 am, the time the UPNG day begins, and exams are on. Hank is supervising. As the examinees await permission to begin, one of them, Ekeroma Age, beckons to him and points to an empty desk. 'Claire must be still asleep, Hank', he says. 'You'd better go and wake her up'. So the lecturer sprints off to the women's dormitory and wakes Claire, just in time for her to get to the exam. This may be a story about the singularity of UPNG in those days, as well as about Hank.

In 1973 the Nelsons moved to Canberra, where Hank embarked on the thesis about gold mining that made him Dr Nelson and became in 1977 the book Black, White and Gold. As a PhD student he had been housed in the Research School of Social Sciences. Then he moved to the other side of the Coombs building to what in those days was called the Research School of Pacific Studies, and there he remained for the rest his life. At ANU he took to new fields of study prisoners of the Japanese, bush schools, Australians in Bomber Command, all of them involving use of written and oral sources - while also pursuing subjects gestating from his PNG years.

In his advanced course in PNG history one common topic for oral history exercises was My Village during the War. The Second World War was then just far enough away for Papuans and New Guineans who had lived through it to talk candidly about their experiences, and close enough for their memories of it to be vivid. There's a direct line from the testimonies gathered in that class to 
the award-winning film Angels of War, produced and directed by Hank, Gavan Daws and Andrew Pike in 1982. Hank's other work out that year, Taim Bilong Masta, also draws on the collection of oral histories during Hank's years in PNG, followed up in fertile collaboration with Tim Bowden to create the splendid series of $\mathrm{ABC}$ radio programs on which the book is based.

Hank has become legendary both for his own work and for his wise and selfeffacing contribution to the work of others, young and old, whatever their place on a spectrum from empiricism to postmodernism. In recent years he has written for general readers masterly surveys of the intricacies of contemporary affairs in PNG and elsewhere in Melanesia.

Emeritus Professor Nelson, FASSA, AM. The well-deserved honours didn't actually displease him, but he didn't find it easy to take them with a straight face. He remained the boy from Boort, evoked in a lovely memoir recalling the days when he and his brother John drove to school in a jinker pulled reluctantly by a malevolent horse named Bunny (see 'Pedalling History' in Part II of this book).

I like to imagine him in a posture well remembered by John, in a paddock on the family farm, sitting on a tractor, reading a book. 
This text taken from The Boy from Boort: Remembering Hank Nelson, Edited by Bill Gammage, Brij V. Lal, Gavan Daws, published 2014 by ANU Press, The Australian National University, Canberra, Australia. 